\title{
Isolation and patch size drive specialist plant species density within steppe islands: a case study of kurgans in southern Ukraine
}

\author{
Iwona Dembicz $^{1}$ (D) - Ivan I. Moysiyenko² - Anastasia Shaposhnikova ${ }^{2}$. \\ Denys Vynokurov ${ }^{3} \cdot$ Łukasz Kozub $^{1} \cdot$ Barbara Sudnik-Wejcikowska $^{1}$
}

Received: 19 October 2015/Revised: 22 February 2016/Accepted: 3 March 2016/

Published online: 19 March 2016

(C) The Author(s) 2016. This article is published with open access at Springerlink.com

\begin{abstract}
The fragmentation and isolation of preserved habitat patches within intensive agricultural landscape threaten species survival in steppes. In Ukraine, $<5 \%$ of the original steppe area has survived, mostly in nature reserves, loess ravines and kurgans (burial mounds). The latter are small, but relatively numerous objects. The aim of this study was to investigate whether plant species density (= the number of species per plot) within small steppe patches on kurgans differs from that within large steppe enclaves in southern Ukraine. Another aim was to determine the influence of patch area, isolation and heat load index on species density on kurgans. Presence-absence data for vascular plant species were collected on plots of a size of 100 and $1 \mathrm{~m}^{2}$. Thirty kurgans and ten sites within large steppe enclaves were sampled. Every noted species was classified as specialist or generalist. For kurgans data on area and degree of isolation were collected. Additionally the heat load index for plots on kurgans was calculated. The density of habitat specialists was higher in larger steppe enclaves than on kurgans at both spatial scales. On kurgans the most important predictors of specialist density were isolation (negative) and kurgan area (positive). The density of generalists was positively affected by the heat load index. Kurgans can provide refuges for steppe plant species. However, our results show that over a longer time period, proximity to larger steppe refuges is important to maintain species diversity within these small patches.
\end{abstract}

Communicated by Johannes Kamp.

Electronic supplementary material The online version of this article (doi:10.1007/s10531-016-1077-y) contains supplementary material, which is available to authorized users.

Iwona Dembicz

i.dembicz@biol.uw.edu.pl

1 Department of Plant Ecology and Environmental Conservation, Faculty of Biology, Institute of Botany, University of Warsaw, Al. Ujazdowskie 4, 00-478 Warsaw, Poland

2 Department of Botany, Kherson State University, Str. 40 let Oktriabrya 27, Kherson 73000, Ukraine

3 M.G. Kholodny Institute of Botany of the National Academy of Sciences of Ukraine, Str. Tereshchenkivska 2, Kiev 01601, Ukraine 
Keywords Fragmentation $\cdot$ Habitat island $\cdot$ Habitat specialist $\cdot$ Species density $\cdot$ Species richness - West Pontic grass steppe

\section{Introduction}

Anthropogenic habitat loss and fragmentation are major threats to biodiversity worldwide and their negative effect on the environment are considered one of the most important issues in nature conservation (Wilcox and Murphy 1985; Sih et al. 2000; Fahrig 2003). The influence of the size and isolation of habitat islands for plant species richness and density has been the subject of intense, experimental (Debinski and Holt 2000 and cited literature) and observational research, the latter including a broad range of ecosystems (Fahrig 2003; Ibáñez et al. 2014). Unlike islands located in the ocean, continental habitat islands are usually characterized by their smaller size. Another difference is that the movement of individual species between habitat islands is less restricted due to the permeability of the matrix surrounding these habitat patches (Laurance 2008). Habitat islands can be both of natural (Horsák et al. 2012; Liira et al. 2014) or anthropogenic origin (Rejmánek and Rejmánková 2002; Krauss et al. 2004). Habitat islands resulting from habitat loss due to anthropogenic activities are usually characterized by a shorter period of isolation (usually in the order of tens or hundreds of years). This can cause potential problems associated with the detection of long-term processes such as colonization and extinction of species occurring on islands, for example due to the phenomenon known as extinction debt (Cousins 2009; Kuussaari et al. 2009). Research on the influence of habitat loss and fragmentation on species richness could help to plan protected areas and their spatial arrangement (Niebuhr et al. 2015).

Theoretically, depending on the size and the degree of isolation of habitat patches the so called island effect on species richness could be more or less pronounced (Fahrig 2013). Usually, when islands are smaller and more isolated, the chances of colonization from outside and survival of species within the island are lower. This could result in (1) the species-area relationship for habitat islands having a steeper slope compared to the speciesarea relationship within a continuous habitat; (2) smaller islands having a smaller number of species in randomly selected plots of the same size than larger islands (MacArthur and Wilson 1967; Rosenzweig 2004; Fahrig 2013). These consequences have methodological implications for the study of the island effect on species richness. As argued by Fahrig (2013) research on the effect of isolation on the species richness of habitat islands conducted within fixed plots of the same size (i.e. not on the number of species from the entire area of islands) provide better opportunities to test hypotheses about the impact of these factors. This approach eliminates the 'patch size effect' (Fahrig 2013). Moreover, because diversity patterns, as well as the influence of environmental factors on species richness could strongly depend on spatial scale, comparing plots of different fixed sizes allows for comparison of species density at different spatial scales (Dengler et al. 2014; Turtureanu et al. 2014). Recently, studies focusing on the influence of island effects on plant species richness increasingly used the number of species within fixed-size plots, often referred to as species density (Magurran 1988) as a measure of species richness (Krauss et al. 2004; Cousins et al. 2007; Öster et al. 2007; Munguía-Rosas and Montiel 2014).

The Eurasian steppe, a large grassland belt stretching from Ukraine to Manchuria (Chibilyov 2002), has been greatly transformed and fragmented by human activity 
(Henwood 1998). It is very easy to convert steppe into farmland, as it is very homogenous with poorly developed hydrographic networks, with relatively flat topography and an almost complete absence of forests and wetlands. Moreover, the often high fertility of steppe soils makes them very attractive for agriculture. Due to these reasons, the steppe zone today is the most important agricultural region of Northern Eurasia and North America. About $57 \%$ of the global area occupied by chernozems, soils which developed under steppe vegetation, is used as arable land. However, in some areas like Ukraine, Central Chernozem Region of Russia, the Volga Region, and Kazakhstan even more steppe territory is used for agriculture-estimates range between 74 and $91 \%$ (Chibilyov 2002). Moreover, the remaining steppe areas are often degraded or destroyed by overgrazing, afforestation, urbanization and the creation of open cast mines. Thus natural steppe vegetation remains only on a small portion of its original area (Chibilyov 2002).

In Ukraine, the steppe historically covered approximately $40 \%$ of the total territory of the country, but today steppe remnants exist only on $1 \%$ of this territory, and their effective conservation is difficult due to the high level of fragmentation. For example, in Luhansk region there are about 2000 patches of steppe vegetation (Burkovskyi et al. 2013). During the last two millennia, the area under steppe vegetation in Ukraine decreased 40-fold, while the forest area in the same period decreased three-fold, from 50 to $17 \%$ (Burkovskyi et al. 2013), which highlights the disproportionally high amount of steppe habitat loss. The geographical and ecological isolation of the remaining steppe patches in Ukraine can generally be traced back 100-200 years, when the conversion from steppe to arable land began (early nineteenth century to the first decades of the twentieth century, Lisetskii 1992). The remaining steppe areas occupy several types of refuges: nature reserves (the largest patches, but relatively few), slopes of river valleys, loess ravines (usually large, several kilometres long) and kurgans.

Kurgans (burial mounds, barrows) are earth or earth-stone mounds built from a local substrate (predominantly loess) by ancient cultures and used as burial sites. Kurgans are an integral part of all Eurasian steppe landscapes (Petô and Barczi 2011). Across the Ukrainian steppe, large numbers of barrows were preserved until today, whereas across the Eurasian steppe belt, many kurgans were destroyed by ploughing or archaeological excavations. The current number of kurgans in Ukraine is estimated at approximately 150,000 (Mozolevskiy and Polin 2005). In southern Ukraine they were built 7005000 years ago, most of them by the Yamna Culture (Chernyakov 1993), at a time when the landscape was dominated by pristine steppe. The size of kurgans varies-their diameter can range from 10 to $110 \mathrm{~m}$ and their height can be from $1 \mathrm{~m}$ up to $15 \mathrm{~m}$ (Mozolevskiy and Polin 2005). The flora of many of the remaining barrows has proved to be very rich and of high conservation value (Moysiyenko and Sudnik-Wójcikowska 2010; Deák et al. 2016, this issue). Species composition of the mounds generally reflects the structure and characteristics of vegetation of the steppe zone within which the kurgan is situated (Moysiyenko and Sudnik-Wójcikowska 2006; Sudnik-Wójcikowska and Moysiyenko 2010). Kurgans are refuges, which occur relatively frequently in the landscape, and thus can play an important role in steppe conservation, despite their small size. Nevertheless, the isolation of populations of plants occurring on kurgans entails potential problems such as reduced gene flow between populations, impaired spread of diaspores and higher extinction risk of single species due to stochastic factors such as fire, pathogens and disease (Lienert 2004).

The work presented here is the first to use steppe patches on kurgans to explore issues related to island effects such as the influence of spatial isolation and size on plant diversity. The present study is also pioneering in that it explores the effects of habitat fragmentation 
on plant communities of natural, continuously existing Eurasian steppe, in contrast to a number of already published papers focusing on extrazonal semi-natural dry grasslands of northern and western Europe (i.a. Lindborg and Eriksson 2004; Adriaens et al. 2006; Öster et al. 2007; Reitalu et al. 2009; Evju et al. 2015), which are dependent on human activities and since the early Holocene have not dominated the landscape (Pärtel et al. 2005).

The aim of the present study is to investigate the influence of local and landscape factors on the species richness of steppe plant communities on kurgans in comparison with large steppe enclaves. Specifically the following questions are addressed: (1) Is there a difference between the densities of habitat specialists and generalists on kurgans and larger steppe enclaves, and does the spatial scale of measurement affect the degree of difference? (2) What are the effects of the size and degree of isolation of small habitat islands on the number of species present at different spatial scales? (3) Are the processes typical for habitat islands - such as the extinction of less common, specialist species-detectable in the flora of kurgans?

\section{Methods}

\section{Research area}

Field sampling was conducted in the Kherson region of southern Ukraine (Fig. 1), which is in the Black Sea Lowland of the West Pontic grass steppe zone (Bohn et al. 2004). Sampled sites were concentrated along the Dnipro river due to natural (the presence of loess ravines on the sides of the main river valleys) and historical reasons (the majority of kurgans were built close to the ancient settlements and trading routes associated with the Dnipro river). The plots were situated within an area of approx. $75 \mathrm{~km}$ in the meridional direction and $160 \mathrm{~km}$ in the latitudinal direction at altitudes of 17-87 m.a.s.l. The climate of the region is continental with a mean annual temperature of $9-11{ }^{\circ} \mathrm{C}$ and an annual precipitation sum of 350-400 mm. Most of the annual rainfall is concentrated in May-June and in October (the second peak during the year generally experiences less precipitation than the spring peak), and summer is a period of drought (Marynych and Shyshchenko 2005). The landscape of the region is characterized by slightly undulating plains (Rudenko 2007). Loess is the prevailing surface geological formation, reaching a thickness of several tens of meters (Boiko 1998). On the basis of this loess layer, fertile chernozem and dark chestnut soils have developed. Loess is susceptible to water erosion, and therefore vast loess ravines ('balkas') often arise, dissecting the monotonous, flat landscape. On the steep slopes of relatively young ravines and on the embankments of river valleys, outcrops of limestone of Miocene age can be found (Boiko 1998), however many loess ravines (especially older ones) have mild slopes stretching over a large area and covered with a thick layer of loess.

The West Pontic steppe is the south-westernmost representative of the true steppes of Eurasia (Bohn et al. 2004). The West Pontic grass steppe compared to steppe vegetation located further to the north (in order from the south: herb-grass steppe, meadow steppe and forest steppe) has lower floristic richness, less aboveground biomass, lower average height of vegetation, and less flowering aspects during the year, but it has larger coverage of tussock grasses and more underground biomass. A main characteristic of the grass steppe is that many species enter dormancy during the summer drought (Chibilyov 1990; Bohn et al. 2004). This type of vegetation is dominated by grasses belonging to genera Stipa, Festuca 


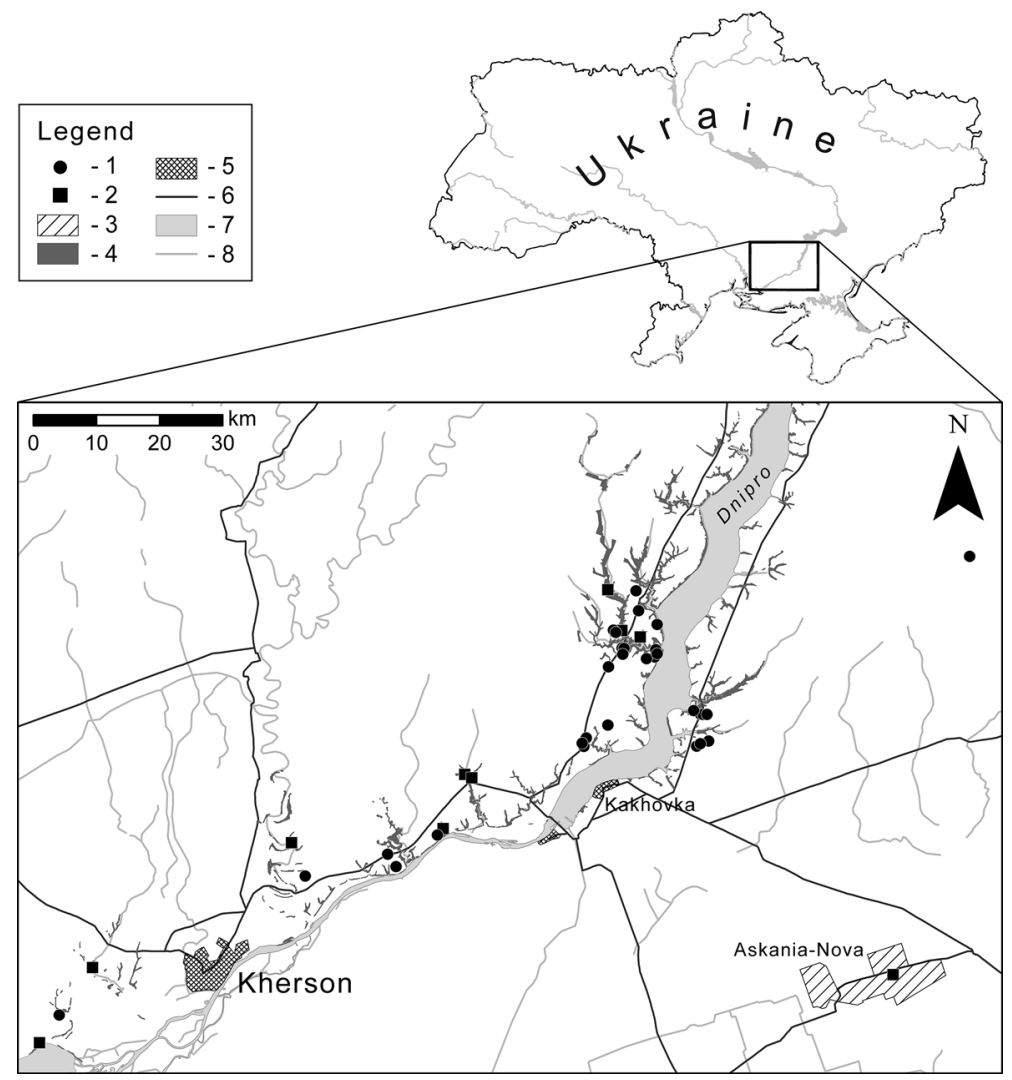

Fig. 1 The study area and location of the sampling plots: 1 sampling plots on kurgans, 2 sampling plots within large steppe enclaves, 3 Askania-Nova Biosphere Reserve, 4 loess ravines (only ravines within a $3 \mathrm{~km}$ radius from sampled sites on kurgans are shown), 5 urban areas, 6 main roads, 7 large rivers/estuaries, 8 minor watercourses

and Koeleria. Herbs have low abundance and richness, and are represented within the study area by Galatella villosa, Kochia prostrata, Phlomis pungens, Jurinea arachnoidea, Tanacetum millefolium and Salvia nutans. A specific feature of this type of steppe is the large share of spring ephemerals (Erophila verna, Holosteum umbellatum, Veronica praecox, V. polita, V. verna, Vicia lathyroides) and ephemeroids (Gagea pusilla, G. szovitsii, G. paczoskiana, G. ucrainica, Tulipa biebersteiniana, T. gesneriana, Hyacinthella leucophaea, Ornithogalum kochii, Iris pumila etc., Lavrenko et al. 1991; Bohn et al. 2004). The vegetation of this steppe zone is classified as the class Festuco-Brometea BraunBlanquet et Tüxen ex Soó 1947 and order Festucetalia valesiacae Braun-Blanquet et Tüxen ex Braun-Blanquet 1949 (Solomakha 2008; Vynokurov 2014).

\section{Field sampling}

In total, data from 40 plots (comprising 1000 subplots) were collected, of which 30 were located on kurgans and 10 in large steppe patches (see Figs. 1, 2). Plot size was $10 \times 10 \mathrm{~m}$. Twenty five subplots of $1 \times 1 \mathrm{~m}$ were uniformly distributed within the larger $10 \times 10 \mathrm{~m}$ 

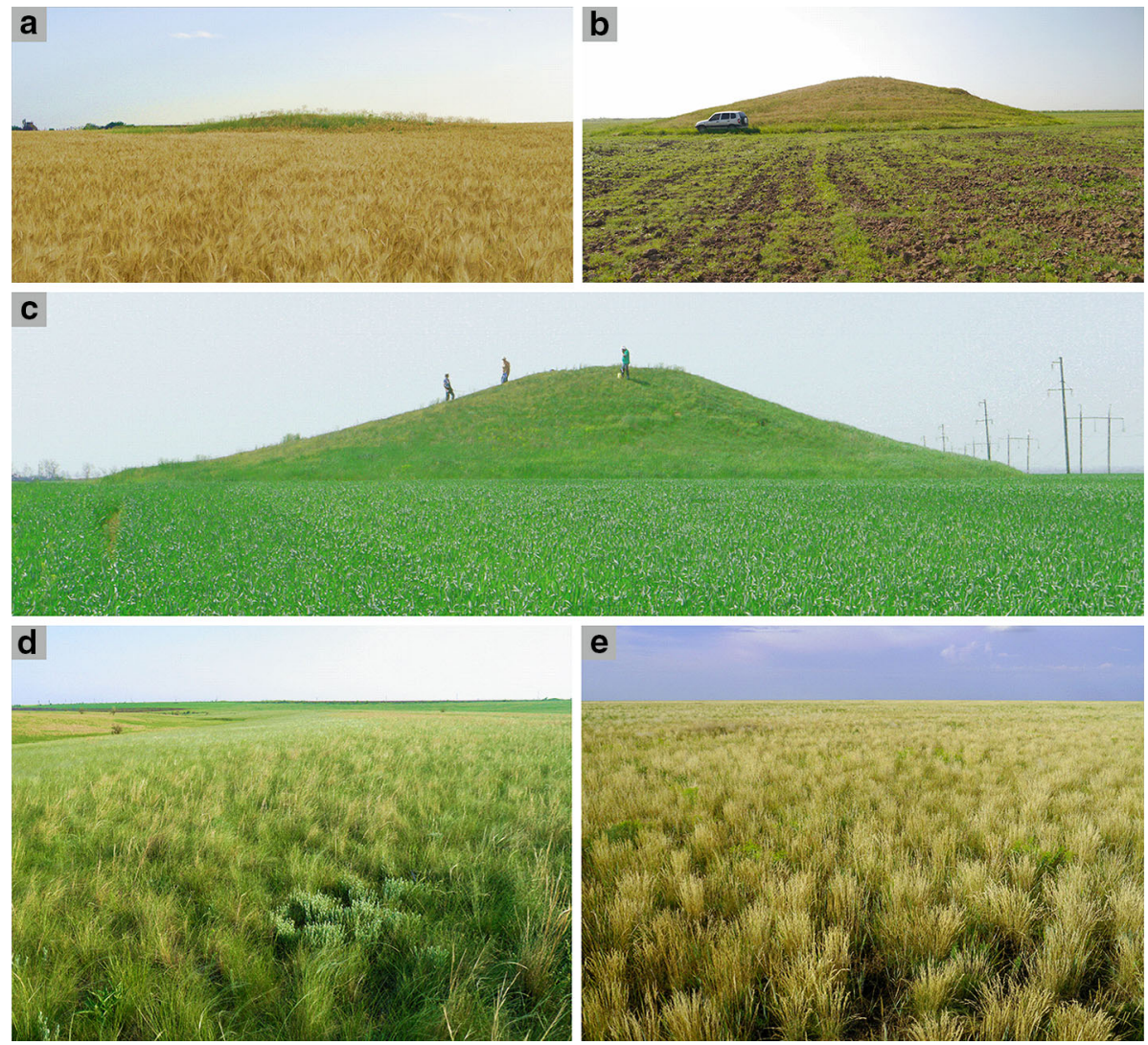

Fig. 2 Kurgans in the investigated area of southern Ukraine differ significantly in size: from very small objects, hardly visible among large fields (a) and medium-sized kurgans, 2-4 m in height (b) to the largest ones, usually 5-8 $\mathrm{m}$ in height (c). Large steppe enclaves in the study area include mostly loess ravines such as Kam'yanska Balka (d). Askania-Nova Biosphere Reserve is the only patch of preserved steppe within the study area located outside of the Dnipro river valley system (e)

plot. Presence-absence data on all vascular plants species were taken from all subplots and from the whole large plot (by adding the species, which were noted outside the subplots). A plant was counted if any aboveground part of it was present within the plot. On kurgans, the slope aspect and slope inclination within plots were also measured. The above mentioned variables were used to calculate the heat load index (Parker 1988, Olsson et al. 2009), as cos (slope aspect - 225) $\times \tan$ (slope angle), where aspect is deviation from the north (in degrees) and slope angle is expressed in degrees as well. When the sampling plot covered the top of the smallest kurgans (which tend to be relatively flat) and the edges of the plot had all possible aspects and a small inclination (less than five degrees), the inclination of the whole sampling plot was assumed to be zero and therefore the value of the calculated heat load index was also zero (Table 1 and Online Resource 1).

Steppe patches on kurgans were measured in the field (length, width and height) and their area was calculated using the equation for an area of a cone with an elliptic base. The calculated area of sampled steppe patches on kurgans varied from 208 to $3057 \mathrm{~m}^{2}$ (Table 1 , for details see Online Resource 1). The area of steppe patches on kurgans is henceforth 
Table 1 Summary of all environmental variables measured on kurgans $(n=30)$ in southern Ukraine

\begin{tabular}{lllllll}
\hline & Mean & SD & Min. & Max. & Predictor & Data transformation \\
\hline Kurgan area $\left(\mathrm{m}^{2}\right)$ & 1607.4 & 837.45 & 208.4 & 3056.5 & + & - \\
Distance $(\mathrm{m})$ & 1355 & 1797.5 & 250 & 10,500 & - & - \\
Habitat amount index & 26.7 & 20.09 & 0.0 & 86.7 & + & sqrt \\
Heat load index & -0.076 & 0.2110 & -0.466 & 0.364 & + & - \\
\hline
\end{tabular}

Those included further in regression analysis as predictors of plant species densities are indicated with "+". Kurgan area the area of steppe patch on a kurgan calculated from field measurements, Distance distance of a kurgan to the nearest large steppe enclave (loess ravine), Habitat amount index the measure of spatial isolation of a steppe patch on a kurgan indicating the area of potential steppe refuges in a vicinity of a kurgan, Heat load index the measure of diurnal heat load calculated from slope aspect and slope inclination within sampling plots

referred to as kurgan area even though the real size of a kurgan could be larger as the bases of kurgans often were ploughed in the past. Fieldwork was conducted during May and in the first half of June in 2012 and 2013.

Kurgans selected for the study were not ploughed in the past (as determined by the vegetation cover and archaeological literature). All studied kurgans were surrounded with arable land. Criteria of selection were area and isolation of kurgans to cover the widest possible gradient of both characteristics. Kurgans situated close to settlements were not studied to avoid the influence of possible management (grazing). No minimal distance between sampled kurgans was set. However, the closest proximity between sampled kurgans was around $100 \mathrm{~m}$. Only one sampling plot was placed on each kurgan. For this purpose the most homogenous and best preserved patch of steppe vegetation was selected to omit the influence of increased environmental heterogeneity and disturbances on species density. On large kurgans sampling plots were located only on their slopes, as typical steppe vegetation occurs within these 'microhabitats', contrary to the top and feet of a kurgan constituting other 'microhabitats' (Sudnik-Wójcikowska and Moysiyenko 2008). On small kurgans sampling plots sometimes also covered the top of the kurgan, as the vegetation on such objects was homogenous (no 'microhabitats' could be distinguished).

As a comparative reference for continuous steppe vegetation, the best preserved steppe patches within old loess ravines in the Dnipro river valley system (nine sampling plots) and within Askania-Nova Biosphere Reserve (one sampling plot) were selected. The sampling sites within large areas of natural vegetation were chosen to cover the same geographical distance and to the extent possible the same range of habitat conditions (slope, aspect) as the kurgan plots. Again the closest proximity between these sampling plots was $100 \mathrm{~m}$, though in this case habitat conditions and the vegetation structure changed considerably over this short distance. Within loess ravines, plots were situated on relatively flat areas or gentle slopes with loess cover, without outcrops of limestone in order to avoid the possible influence of increased habitat heterogeneity on species density. In Askania-Nova Biosphere Reserve, which is located outside the Dnipro river valley system, the plot was located within the oldest part of the protected steppe area. The area of continuous steppe vegetation within each of sampled loess ravines is larger than 10 ha. Within Askania-Nova Biosphere Reserve the virgin steppe covers 11,000 ha. However, it should be noted that the exact area of steppe patches within loess ravines is hard to estimate as they are long, narrow, and irregularly shaped objects, often intersected by roads or villages, though still 
generally forming well-connected systems. Thus the area of steppe vegetation within large refuges was not used as a factor in the analyses.

\section{Patch isolation estimation}

In order to estimate the degree of isolation of steppe patches on kurgans, the distance from each kurgan to the edge of the nearest large steppe patch (loess ravine) was measured. This measure is henceforth referred to as distance (data available in Online Resource 1). Moreover, the area of potential steppe flora refuges within a radius of one, two and three $\mathrm{km}$ from each of the investigated kurgans was mapped. The mapping covered only nonafforested and non-ploughed patches of dry grasslands within loess ravines and river escarpments without intensive human disturbance larger than 0.5 ha. Due to the lack of accurate information for Ukraine in the CORINE database, photo interpretation of potential steppe patches based on satellite images available on Google and Bing maps was conducted. Mapping of potential steppe flora refuges was based on prior knowledge about the location of different types of non-forest vegetation (steppe, reeds, fallow, ruderal vegetation). The colour and texture of known patches on satellite images was used to distinguish refuges of steppe flora from other non-forest vegetation types and to locate and delineate other patches similar in appearance to known refuges of steppe flora. During the mapping a few patches selected on the basis of satellite images as refuges of steppe flora not visited by the authors before were surveyed to confirm that they were classified appropriately. Mapping of steppe enclaves and measurements were performed using QGIS software (QGIS Development Team 2014). For subsequent analyses we calculated a habitat amount index, which is a modification of patch isolation buffer measurements widely used in landscape ecology (Moilanen and Nieminen 2002). The habitat amount index for each kurgan was calculated on the basis of the area of potential steppe flora refuges (steppe habitat amount) within subsequent buffers around a kurgan according to the formula:

Habitat amount index $=$ steppe habitat amount within $1 \mathrm{~km}$ buffer $+0.25 \times$ steppe habitat amount within $2 \mathrm{~km}$ buffer $+0.1 \times$ steppe habitat amount within $3 \mathrm{~km}$ buffer

This index helps to highlight the stronger influence of nearby steppe refuges on the species density of kurgans, as opposed to steppe patches located at a distance of more than $1 \mathrm{~km}$ from the mounds, whose capacity to be a potential source of seeds and pollen is smaller. It is important to note that larger values of the habitat amount index mean lower isolation than smaller values (Table 1, see also Online Resource 1).

\section{Species density and ecological groups}

Collected data included total species numbers for each of the larger 40 plots and the mean number of species within subplots from each of the larger 40 samples. Thus we use either species number per plot or species density according to Magurran (1988) instead of species richness to emphasize that our data were collected within plots of fixed sizes, not on whole areas of habitat islands (where the term species richness would be more proper). To better understand diversity patterns of steppe enclaves and processes that shaped them (especially in the case of kurgans where the flora was rich in weeds coming from surrounding crop fields) a group of habitat specialist species was distinguished by the authors on the basis of their ecology within the study area. Such species are common in well preserved grass steppe, but not usually found in areas under strong human impact. They rarely colonize marginal habitats such as field margins or roadsides (= non-synanthropic, typical steppe 
species of vascular plants) and thus the agricultural matrix of the landscape constitutes a barrier for their dispersal. The species not classified as specialists are henceforth referred to as generalists [for number of species per plots see Online Resource 1, the complete list of observed species with their status see Online Resource 2; species identification and nomenclature by Mosyakin and Fedoronchuk 1999, protection status categories according to Red Data Book of Ukraine (Didukh 2009) and Red List of Kherson Region (2013)].

\section{Data analyses}

To determine whether the species density on kurgans differed from the species density within large steppe enclaves, species density was compared with Mann-Whitney U tests. The test was performed for total species density within large and small plots, and separately for habitat specialists and generalists at both spatial scales. Pearson linear correlation was applied to determine the relationship between species densities at large and small spatial scales for all species and separately for the two ecological groups (habitat specialists and generalists).

Multiple regression analysis was used to investigate the relationship of measured environmental variables with species richness values collected from kurgans. Before the analyses, the data distribution of all variables was visually assessed using Q-Q plots created in R 3.1.1 ( $\mathrm{R}$ Core Team 2014). Data transformation was applied for habitat amount index (square root), and for distance $\left(\log _{10}\right)$ as the original data were strongly skewed. The explanatory variables were checked for collinearity using Pearson correlation with thresholds of correlation coefficients between predictor variables of $|r|>0.7$ (Dormann et al. 2013). As there was strong collinearity between log-transformed distance and square root of habitat amount index $(\mathrm{r}=-0.836, p<0.0001)$, only the latter was used in further analyses. As assumptions concerning the normality and the independence of explanatory variables were fulfilled, linear models (only models without interactions of variables) were fitted to data sets on both spatial scales, for all species of vascular plants and for habitat specialists and generalists separately. Linear regression models were computed using function ' $\mathrm{lm}$ ' in R 3.1.1. Subsequently, model selection was performed using the R-package MuMIn version 1.14 (Bartoń 2015). Models containing all possible variable combinations were built starting from a full model. An information-theoretical approach was followed to compare the fit of the different models (Burnham and Anderson 2002). All obtained models with $\Delta \mathrm{AIC}_{\mathrm{C}}<2$ were retained and are discussed further as the set of best-supported models. The relative importance of single variables $\left(w_{+}(j)\right)$ was quantified as the sum of Akaike weights over all models including that particular explanatory variable (Burnham and Anderson 2002). Variable coefficients were averaged over all models using the function 'model.avg' in MuMIn. Additionally, to show the explanatory power of measured environmental variables for species density values within investigated species groups, adjusted $\mathrm{R}^{2}$ were calculated for all models. A visual examination of the plot of standardized residuals as a function of standardized predicted values for all models where $\Delta \mathrm{AIC}_{\mathrm{C}}<2$ was performed, to check whether the linear regression assumptions were met. All the considered regression models fulfilled the assumptions of linearity of relationship between the independent and dependent variables, and homoscedasticity. 


\section{Results}

Within all 40 plots a total of 250 species of vascular plants were recorded, 135 of which were steppe habitat specialists (Online Resource 2). From the species recorded on kurgans, 59 species (23 specialists) were not present in other steppe refuges while 68 species (48 specialists) were found only in large steppe patches. The overall species density in $100 \mathrm{~m}^{2}$ plots varied from 21 to 73 species while within the same plots from seven to 53 species of habitat specialists were recorded (Table 2). Across all sampled $1 \mathrm{~m}^{2}$ plots the overall species number was between two and 28 while the number of habitat specialists varied from zero to 24 species per plot.

The density of all species in the $100 \mathrm{~m}^{2}$ plots was significantly lower in samples from kurgans than in those from large steppe enclaves, but this was not the case for the $1 \mathrm{~m}^{2}$ plots (Table 2). The density of habitat specialists in large steppe enclaves was significantly higher than on kurgans at both spatial scales (Table 2). The number of all species within large plots was strongly correlated with the mean number of species in small plots $(\mathrm{r}=0.821, p<0.0001)$. Similar results were obtained after separating habitat specialists from generalists. For both groups their densities in large and their mean densities in small plots were also correlated $(\mathrm{r}=0.920, p<0.0001$ for habitat specialists and $\mathrm{r}=0.834$, $p<0.0001$ for generalists).

All explanatory variables were predictors of total species number within the $100 \mathrm{~m}^{2}$ plots on kurgans, with heat load index and habitat amount index being the most important ones suggesting a positive relationship (Tables 3,4). For the number of habitat specialists within $100 \mathrm{~m}^{2}$ plots on kurgans all predictors were also included in the set of best-

Table 2 Descriptive statistics and results of Mann-Whitney U test for comparison of the number of all species, habitat specialists and generalists on kurgans ( $n=30)$ and within large steppe enclaves $(n=10)$ in southern Ukraine within sampling plots of 100 and $1 \mathrm{~m}^{2}$

In the case of small plots each sample is the mean calculated from 25 subplots. $n s$ nonsignificant $(p$ value $>0.05)$

\begin{tabular}{|c|c|c|c|c|c|}
\hline & Mean & SD & Min. & Max. & $p$ \\
\hline \multicolumn{6}{|l|}{ All species } \\
\hline \multicolumn{6}{|l|}{ Large plots $-100 \mathrm{~m}^{2}$} \\
\hline Kurgans & 42.3 & 11.52 & 21 & 58 & $<0.05$ \\
\hline Large steppe enclaves & 53.5 & 12.68 & 30 & 73 & \\
\hline \multicolumn{6}{|l|}{ Small plots $-1 \mathrm{~m}^{2}$} \\
\hline Kurgans & 11.8 & 3.60 & 4.5 & 18.4 & ns \\
\hline Large steppe enclaves & 14.4 & 4.60 & 8.2 & 21.9 & \\
\hline \multicolumn{6}{|l|}{ Habitat specialists } \\
\hline \multicolumn{6}{|l|}{ Large plots $-100 \mathrm{~m}^{2}$} \\
\hline Kurgans & 16.7 & 5.63 & 7 & 29 & $<0.0005$ \\
\hline Large steppe enclaves & 30.0 & 9.75 & 16 & 53 & \\
\hline \multicolumn{6}{|l|}{ Small plots $-1 \mathrm{~m}^{2}$} \\
\hline Kurgans & 5.3 & 2.00 & 1.5 & 10.0 & $<0.005$ \\
\hline Large steppe enclaves & 9.2 & 3.80 & 6.0 & 18.7 & \\
\hline \multicolumn{6}{|l|}{ Generalists } \\
\hline \multicolumn{6}{|l|}{ Large plots $-100 \mathrm{~m}^{2}$} \\
\hline Kurgans & 25.6 & 10.26 & 8 & 41 & ns \\
\hline Large steppe enclaves & 23.5 & 8.59 & 12 & 42 & \\
\hline \multicolumn{6}{|l|}{ Small plots $-1 \mathrm{~m}^{2}$} \\
\hline Kurgans & 6.4 & 3.50 & 1.2 & 13.2 & ns \\
\hline Large steppe enclaves & 5.2 & 3.20 & 1.2 & 11.5 & \\
\hline
\end{tabular}


Table 3 Averaged coefficients (Av. coef.) and importance $\left(w_{+}(j)\right)$ of individual regression predictors in models explaining species densities on kurgans in southern Ukraine within $100 \mathrm{~m}^{2}$ plots $(n=30)$ and $1 \mathrm{~m}^{2}$ plots ( $n=30$, from every kurgan only the mean from 25 such plots was used in the models)

\begin{tabular}{|c|c|c|c|}
\hline Group of species & Predictor & Av. coef. & $\left(w_{+}(j)\right)$ \\
\hline \multirow[t]{3}{*}{ All species-100 $\mathrm{m}^{2}$} & A & 0.002 & 0.34 \\
\hline & $\mathrm{HL}$ & 32.848 & 1.00 \\
\hline & $\operatorname{sqrt}(\mathrm{HA})$ & 1.893 & 0.77 \\
\hline \multirow[t]{3}{*}{ Habitat specialists $-100 \mathrm{~m}^{2}$} & A & 0.004 & 1.00 \\
\hline & $\mathrm{HL}$ & 5.989 & 0.56 \\
\hline & sqrt(HA) & 1.828 & 1.00 \\
\hline \multirow[t]{3}{*}{ Generalists-100 m } & A & -0.002 & 0.30 \\
\hline & $\mathrm{HL}$ & 28.720 & 1.00 \\
\hline & $\operatorname{sqrt}(\mathrm{HA})$ & 0.423 & 0.23 \\
\hline \multirow[t]{3}{*}{ All species- $-1 \mathrm{~m}^{2}$} & A & 0.001 & 0.32 \\
\hline & $\mathrm{HL}$ & 9.632 & 0.99 \\
\hline & $\operatorname{sqrt}(\mathrm{HA})$ & 0.256 & 0.29 \\
\hline \multirow[t]{3}{*}{ Habitat specialists $-1 \mathrm{~m}^{2}$} & A & 0.002 & 1.00 \\
\hline & $\mathrm{HL}$ & -0.085 & 0.19 \\
\hline & sqrt(HA) & 0.504 & 0.99 \\
\hline \multirow[t]{3}{*}{ Generalists $-1 \mathrm{~m}^{2}$} & A & -0.001 & 0.32 \\
\hline & $\mathrm{HL}$ & 10.502 & 1.00 \\
\hline & $\operatorname{sqrt}(\mathrm{HA})$ & -0.111 & 0.22 \\
\hline
\end{tabular}

Variable coefficients were averaged over all possible models. Importance $\left(w_{+}(j)\right)$ was quantified as the sum of Akaike weights over all models including that particular explanatory variable. $A$ kurgan area, $H L$ heat load index (the measure of diurnal heat load calculated from slope aspect and slope inclination within plots), $\operatorname{sqrt}(H A)$ square root of the habitat amount index (the measure of spatial isolation of a kurgan indicating the area of potential steppe refuges in the vicinity of a kurgan). Importance values $\geq 0.5$ are marked in bold

supported models, however the most important predictors (both positive) were kurgan area (Fig. 3) and habitat amount index (Tables 3, 4). In turn the most important predictor explaining differences in number of generalist species within $100 \mathrm{~m}^{2}$ plots on kurgans was heat load index. Kurgan area had a negative influence on the number of generalist species in the set of best-supported models, but the importance of this predictor was low (Table 3; Fig. 3).

At the smaller spatial scale, differences between the investigated ecological groups in terms of factors explaining species density on kurgans were even more pronounced (Tables 3, 4). Heat load index was the most important positive predictor of the average species number in $1 \mathrm{~m}^{2}$ plots in the case of both all and generalists species (Table 3; Fig. 3). Again the set of best-supported models included also kurgan area, but it had low importance (Table 3). In contrast, the number of habitat specialists in $1 \mathrm{~m}^{2}$ plots on kurgans was explained only by habitat amount index and kurgan area, both with positive effects and highly important (Tables 3, 4).

The percentage of explained variance was generally higher in models for habitat specialists, than in models for all species and generalists (Table 4). The highest explanatory power was obtained in models for the number of habitat specialists in $100 \mathrm{~m}^{2}$ plots, 
Table 4 Results of model selection explaining the plant species densities in steppe plots on kurgans $(n=30)$ in southern Ukraine

\begin{tabular}{|c|c|c|c|c|}
\hline Set of candidate models & AICc & $\Delta \mathrm{AICc}$ & $w_{i}$ & Adj. $R^{2}$ \\
\hline \multicolumn{5}{|l|}{ All species-100 $\mathrm{m}^{2}$} \\
\hline $1+\operatorname{sqrt}(\mathbf{H A})+\mathbf{H L}$ & 224.06 & 0.00 & 0.48 & 0.40 \\
\hline $\mathbf{1}+\mathbf{A}+\operatorname{sqrt}(\mathbf{H A})+\mathbf{H L}$ & 225.08 & 1.02 & 0.29 & 0.41 \\
\hline $1+\mathrm{HL}$ & 226.09 & 2.04 & 0.17 & 0.32 \\
\hline $1+\mathrm{A}+\mathrm{HL}$ & 228.51 & 4.45 & 0.05 & 0.30 \\
\hline $1+\operatorname{sqrt}(\mathrm{HA})$ & 235.99 & 11.93 & 0.00 & 0.05 \\
\hline 1 & 236.25 & 12.19 & 0.00 & - \\
\hline $1+\mathrm{A}+\operatorname{sqrt}(\mathrm{HA})$ & 238.44 & 14.38 & 0.00 & 0.03 \\
\hline $1+\mathrm{A}$ & 238.72 & 14.66 & 0.00 & -0.04 \\
\hline \multicolumn{5}{|l|}{ Habitat specialists $-100 \mathrm{~m}^{2}$} \\
\hline $\mathbf{1}+\mathbf{A}+\operatorname{sqrt}(\mathbf{H A})+\mathbf{H L}$ & 174.75 & 0.00 & 0.56 & 0.54 \\
\hline $\mathbf{1}+\mathbf{A}+\operatorname{sqrt}(\mathbf{H A})$ & 175.21 & 0.47 & 0.44 & 0.51 \\
\hline $1+\operatorname{sqrt}(\mathrm{HA})$ & 188.76 & 14.01 & 0.00 & 0.18 \\
\hline $1+\mathrm{A}$ & 190.48 & 15.73 & 0.00 & 0.13 \\
\hline $1+\operatorname{sqrt}(\mathrm{HA})+\mathrm{HL}$ & 190.85 & 16.10 & 0.00 & 0.17 \\
\hline $1+\mathrm{A}+\mathrm{HL}$ & 192.05 & 17.30 & 0.00 & 0.13 \\
\hline 1 & 193.31 & 18.56 & 0.00 & - \\
\hline HL & 195.41 & 20.66 & 0.00 & -0.02 \\
\hline \multicolumn{5}{|l|}{ Generalists- $100 \mathrm{~m}^{2}$} \\
\hline HL & 217.00 & 0.00 & 0.53 & 0.35 \\
\hline $\mathbf{A}+\mathbf{H L}$ & 218.59 & 1.58 & 0.24 & 0.35 \\
\hline $\operatorname{sqrt}(\mathrm{HA})+\mathrm{HL}$ & 219.24 & 2.24 & 0.17 & 0.33 \\
\hline $\mathrm{A}+\operatorname{sqrt}(\mathrm{HA})+\mathrm{HL}$ & 221.36 & 4.36 & 0.06 & 0.34 \\
\hline 1 & 228.28 & 11.28 & 0.00 & - \\
\hline A & 228.99 & 11.99 & 0.00 & 0.02 \\
\hline $\operatorname{sqrt}(\mathrm{HA})$ & 230.56 & 13.56 & 0.00 & -0.03 \\
\hline $\mathrm{A}+\operatorname{sqrt}(\mathrm{HA})$ & 231.67 & 14.67 & 0.00 & -0.01 \\
\hline \multicolumn{5}{|l|}{ All species-1 $\mathrm{m}^{2}$} \\
\hline $\mathbf{1}+\mathbf{H L}$ & 155.51 & 0.00 & 0.49 & 0.30 \\
\hline $\mathbf{1}+\mathbf{A}+\mathbf{H L}$ & 157.22 & 1.71 & 0.21 & 0.30 \\
\hline $1+\operatorname{sqrt}(\mathbf{H A})+\mathbf{H L}$ & 157.49 & 1.99 & 0.18 & 0.29 \\
\hline $1+\operatorname{sqrt}(\mathrm{HA})+\mathrm{A}+\mathrm{HL}$ & 158.59 & 3.09 & 0.11 & 0.31 \\
\hline 1 & 164.85 & 9.34 & 0.00 & - \\
\hline $1+\operatorname{sqrt}(\mathrm{HA})$ & 166.96 & 11.45 & 0.00 & -0.02 \\
\hline $1+\mathrm{A}$ & 167.22 & 11.71 & 0.00 & -0.03 \\
\hline $1+\operatorname{sqrt}(\mathrm{HA})+\mathrm{A}$ & 169.34 & 13.83 & 0.00 & -0.05 \\
\hline \multicolumn{5}{|l|}{ Habitat specialists $-1 \mathrm{~m}^{2}$} \\
\hline $1+\operatorname{sqrt}(\mathbf{H A})+\mathbf{A}$ & 114.20 & 0.00 & 0.80 & 0.47 \\
\hline $1+\operatorname{sqrt}(\mathrm{HA})+\mathrm{A}+\mathrm{HL}$ & 117.09 & 2.90 & 0.19 & 0.45 \\
\hline $1+\mathrm{A}$ & 123.51 & 9.31 & 0.01 & 0.24 \\
\hline $1+\mathrm{A}+\mathrm{HL}$ & 126.11 & 11.91 & 0.00 & 0.22 \\
\hline $1+\operatorname{sqrt}(\mathrm{HA})$ & 129.94 & 15.74 & 0.00 & 0.06 \\
\hline
\end{tabular}


Table 4 continued

\begin{tabular}{lllll}
\hline Set of candidate models & AICc & $\Delta$ AICc & $w_{i}$ & Adj. $\mathbf{R}^{2}$ \\
\hline 1 & 130.38 & 16.18 & 0.00 & - \\
$1+$ sqrt(HA) + HL & 132.18 & 17.98 & 0.00 & 0.04 \\
$1+$ HL & 132.41 & 18.21 & 0.00 & -0.02 \\
Generalists-1 m ${ }^{2}$ & & & & \\
$\mathbf{1}+\mathbf{H L}$ & $\mathbf{1 4 8 . 5 4}$ & $\mathbf{0 . 0 0}$ & $\mathbf{0 . 5 3}$ & $\mathbf{0 . 4 1}$ \\
$\mathbf{1}+\mathbf{A}+\mathbf{H L}$ & $\mathbf{1 5 0 . 1 2}$ & $\mathbf{1 . 5 8}$ & $\mathbf{0 . 2 4}$ & $\mathbf{0 . 4 1}$ \\
$1+$ sqrt(HA) + HL & 151.10 & 2.56 & 0.15 & 0.39 \\
$1+$ sqrt(HA) + A + HL & 152.49 & 3.95 & 0.07 & 0.40 \\
1 & 163.09 & 14.56 & 0.00 & - \\
$1+$ A & 163.81 & 15.27 & 0.00 & 0.02 \\
$1+$ sqrt(HA) & 165.45 & 16.92 & 0.00 & -0.03 \\
$1+$ sqrt(HA) + A & 165.81 & 17.27 & 0.00 & 0.01 \\
\hline
\end{tabular}

$\triangle \mathrm{AICc}$ represent the differences between the AICc values of the best models considered and other models. Akaike weight $\left(w_{i}\right)$ indicates the probability that a particular model was best among those considered. Models with $\triangle \mathrm{AICc}<2.0$ were highlighted in bold. Adj. $\mathrm{R}^{2}$ was provided as an estimate of model fit beyond AIC comparisons. Models were run for the data sets at two spatial scales $\left(100 \mathrm{~m}^{2}\right.$ and $\left.1 \mathrm{~m}^{2}\right)$ for all species, and steppe habitat specialist and generalist species separately. $A$ kurgan area, $H L$ heat load index (the measure of diurnal heat load calculated from slope aspect and slope inclination within plots), $\operatorname{sqrt}(H A)$ square root of the habitat amount index (the measure of spatial isolation of a kurgan indicating the area of potential steppe refuges in the vicinity of a kurgan)

whereas the lowest model fit was obtained for total species number in plots of $1 \mathrm{~m}^{2}$ (Table 4).

\section{Discussion}

The obtained results confirm that diversity patterns differed between kurgans and large steppe enclaves both at large and small spatial scales. The most pronounced dissimilarity was detected in the number of habitat specialists, especially at the larger spatial scale (i.e. plots of area $100 \mathrm{~m}^{2}$ ). These results could indicate that species extinctions are not always compensated by immigration on kurgans. The more pronounced difference at large spatial scale can be explained by the faster extinction of less common species, which is more likely to be noted within the larger sampling area. Such species may represent weaker competitors, which are the first to suffer from the effects of habitat loss and fragmentation (Henle et al. 2004). Nevertheless, it is important to highlight the unequal number of sampling units on kurgans (30) and large steppe patches (10) in the present study, which could influence the minimum and maximum recorded species densities. However, it should not influence the results of statistical testing as the nonparametric test used for this study is not strongly biased by extreme values. The difference in sampling effort could be the reason for the relatively large number of habitat specialist species (23) that were found exclusively within the kurgan plots. In general, apart from one species Hylotelephium triphyllum that can only be found on kurgans within the study area, other habitat specialists also occur in larger steppe patches (unpublished data I. I. Moysiyenko). 
Habitat specialists
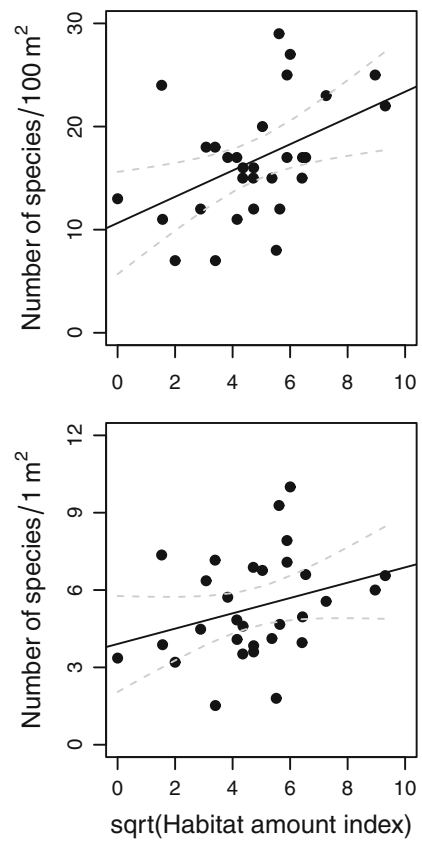
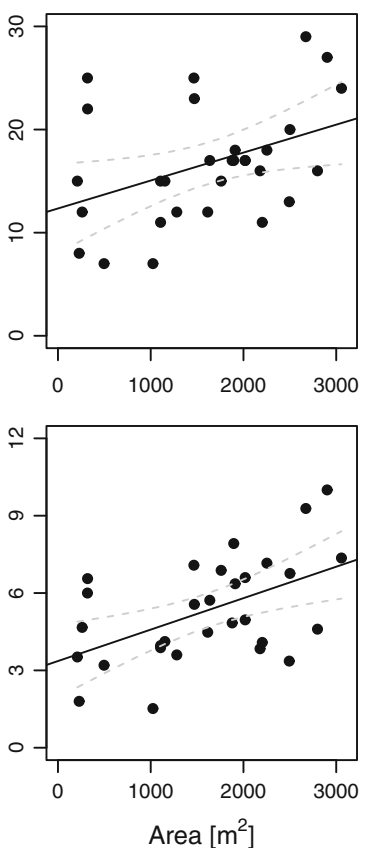

Generalists
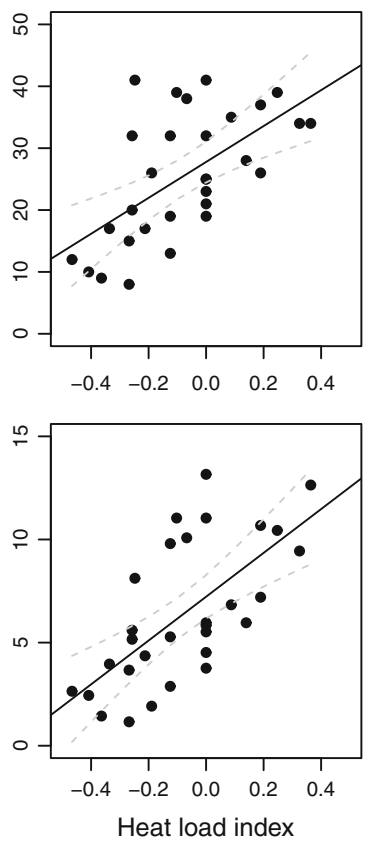

Fig. 3 Influence of the predictors with the highest variable importance (0.99-1) on the densities of specialists and generalists within sampling plots on kurgans $(n=30)$ in southern Ukraine. Importance $\left(w_{+}(j)\right)$ is quantified here as the sum of Akaike weights over all models including that particular explanatory variable. Area kurgan area, Heat load index the measure of diurnal heat load calculated from slope aspect and slope inclination within $100 \mathrm{~m}^{2}$ plots, Habitat amount index the measure of spatial isolation of a kurgan indicating the area of potential steppe refuges in the vicinity of a kurgan (higher values of the index indicate lower isolation). Regression lines are shown with $95 \%$ confidence limits. Habitat amount index was squareroot-transformed

The results of the present research carried out on fixed-size plots located on kurgans confirmed that habitat island area and the amount of suitable habitat in the landscape surrounding the island are major factors explaining total species density of habitat specialists. This is in contrast with a number of studies on the influence of the contemporary island effect on total species density of dry grasslands (Lindborg and Eriksson 2004; Cousins et al. 2007), or species density of habitat specialists (Krauss et al. 2004; Helm et al. 2006), which found no such relationship. Only Öster et al. (2007) confirmed influence of present patch area on density of all species. A possible explanation for this inconsistency between the studies mentioned above and results from the kurgans of southern Ukraine might be an extinction debt still not 'paid' on north-European grasslands. However, it is possible, that on semi-natural grasslands, much more important factors, than patch size and isolation, influence species richness and composition. Those could include contemporary and historical management practices and rate and direction of secondary succession following the cessation of agricultural use. Current management was the main factor determining species density within Swedish semi-natural grasslands, while there was no or only a weak effect of present and past patch area and habitat connectivity (Cousins et al. 2007; Reitalu et al. 2009). In the arid ecosystems of Ukraine, where dry grasslands are a 
zonal vegetation type, the influence of succession or management is not as strong as in the extrazonal dry grasslands of northern Europe and has not overshadowed the influence of habitat fragmentation and isolation, which are the strongest predictors of species density for habitat specialists. In this respect the presented results can be compared more with studies describing effects of anthropogenic fragmentation on other natural ecosystems such as temperate forests (Rodríguez-Loinaz et al. 2012; Valdés et al. 2015), which, similar to the results presented here, confirm the important role of present patch isolation for the density of habitat specialist species.

Kurgans have some characteristics distinguishing them from many other studied habitat islands like their relatively small area, uniform shape and structure, long period of isolation, reaching 200 years (Lisetskii 1992), and a very high degree of anthropogenic transformation of the surrounding landscape. These features of kurgans could suggest that these objects are 'too small' and 'too isolated' for the persistence of certain habitat specialist populations in the long-run and that there should be an extinction threshold in such cases (Kuussaari et al. 2009). Nevertheless, the response of vascular plant species richness could be very slow, as individuals of long-lived plant species can survive for decades or even longer (Helm et al. 2006). The results of the present study suggest that in the case of kurgans extinction of habitat specialists on kurgans has occurred. Furthermore, as the current degree of isolation and the kurgan area are the main predictors of habitat specialist species density on kurgans, the authors conclude that the relaxation time (Kuussaari et al. 2009) has passed, which in turns means that the extinction debt is close to being 'paid' and the species richness on kurgans is approaching a new equilibrium state. This may be an effect of the very small amount of remaining habitat in the landscape as suggested by Cousins (2009).

As in previous studies (Evju et al. 2015; Valdés et al. 2015) no strong influence of isolation on generalist species richness was observed within habitat islands on kurgans in southern Ukraine. Their density seemed to be determined by other, more local, factors. Heat load index turned out to be the most important factor controlling generalist species density on kurgans and it also had a major influence on the total species number per plot. The positive relationship of heat load index with species density is surprising in the harsh environmental conditions of the true steppe zone, where water availability, normally strongly dependant on heat load index (Pausas and Austin 2001), is a main stress factor. The positive relationship between heat load and species density on dry grasslands was also described for northern Europe, where dry grasslands are an extrazonal vegetation type and where higher insolation promotes the maintenance of such vegetation (Olsson et al. 2009). In Transylvania (Romania), in a subcontinental-temperate climate more similar to the one of southern Ukraine, heat load was a strongly negative predictor of alpha-diversity of vascular plants in dry grasslands (Turtureanu et al. 2014). On kurgans of southern Ukraine different ecological groups were investigated separately and thus it may be noted that the positive relationship between heat load index and total species density is actually driven by the group of generalist species. Among those generalist species there is a large share of synanthropic native and non-native species. As also found on kurgans of the desert steppe zone, synanthropic species, especially therophytes and short-living perennials, were well represented in the most extreme microhabitats on these objects, i.e. on the top and southern slopes (Sudnik-Wójcikowska and Moysiyenko 2008). These results to some extent agree with the finding presented here, that heat load index could locally be a positive predictor of species density in the case of generalist (mostly synanthrophic) species. Further studies are needed to explain the mechanisms that stand behind this relationship. 
Even though kurgans in southern Ukraine are only small islets of steppe vegetation scattered in the 'sea' of vast, intensively used crop fields, they have been important refuges for many valuable steppe plant species populations through decades of isolation from continuous habitat (Moysiyenko and Sudnik-Wójcikowska 2006; 2010). Although in the present study a higher density of habitat specialists was found in the larger steppe patches (like loess ravines or nature reserves) than on kurgan plots, the role of kurgans in plant diversity conservation should not be neglected. Kurgans could preserve a considerable share of the populations of several species in the region, e.g. the endemic Limonium bungeanum (Moysiyenko 2008) or Tulipa gesneriana (Perehrym et al. 2009). The protection of steppe species populations may be less effective on highly isolated and small kurgans. On the other hand, the findings of this study provide indirect evidence that the proximity of large steppe enclaves affects plant species diversity on kurgans and can enrich these small 'islets' in steppe plant species probably through colonization processes. Today kurgans in Ukraine are protected as archaeological monuments, however their value as a wildlife refuge is still not recognized by national authorities (On Protection of Cultural Heritage Act 2000). If it is assumed, on the basis of the present study, that steppe specialist plant species can thrive within and also successfully colonize small habitat patches, similarly as it has been observed for insects by Tscharntke et al. (2002), then kurgans can be used to aid the ecological restoration of the steppe (Sudnik-Wójcikowska and Moysiyenko 2011). The knowledge from the present research may be an important argument to strengthen the protection of the natural values of kurgans. This could be done by incorporating them into larger systems of protected areas and creating buffer zones around them (to protect them against ploughing, and to enlarge the areas of these habitat islands). Creation of ecological corridors connecting kurgans is also advisable to enhance migration of non-anemochorous species. However, even kurgans scattered throughout the landscape can be used as 'stepping stones' between the remaining (larger) steppe enclaves.

Acknowledgments We would like to express our gratitude to Prof. Valeriy Akatov from Maikop State Technological Institute for inestimable help and advice in refining the research methodology. We also thank Dr. Viktor Shapoval from Askania-Nova Biosphere Reserve and Yurij Bezukh for help in organizing fieldwork, Dr. Ewa Jabłońska for her guidance in statistical analyses, the editor and four anonymous reviewers for their detailed and constructive comments. The study was funded by The Polish National Science Centre Research Grant № 2013/09/N/NZ8/03234.

Open Access This article is distributed under the terms of the Creative Commons Attribution 4.0 International License (http://creativecommons.org/licenses/by/4.0/), which permits unrestricted use, distribution, and reproduction in any medium, provided you give appropriate credit to the original author(s) and the source, provide a link to the Creative Commons license, and indicate if changes were made.

\section{References}

Adriaens D, Honnay O, Hermy M (2006) No evidence of a plant extinction debt in highly fragmented calcareous grasslands in Belgium. Biol Conserv 133:212-224. doi:10.1016/j.biocon.2006.06.006

Bartoń K (2015) MuMIn: multi-model inference. R package version 1.14.0. https://cran.r-project.org/web/ packages/MuMIn/index.html

Bohn U, Gollub G, Hettwer C et al (eds) (2004) Map of the natural vegetation of Europe. Scale 1:2500000. Interactive CD-ROM: explanatory text, legend, maps. Bundesamt für Naturschutz, Bonn

Boiko M (ed) (1998) Pryroda Khersonskoi Oblasti. Fizyko-geographichnyi narys. Fitosociocentr, Kherson

Burkovskyi O, Vasyliuk O, Yena A et al (2013) Ostanni stepy Ukrainy: buty chy ne buty. Zberezhemo Ukrainski Stepy, Kiev

Burnham KP, Anderson DR (2002) Model selection and multimodel inference: a practical informationtheoretic approach, 2nd edn. Springer, New York 
Chernyakov IT (1993) Kurgani v kul'turí Ukraïni In: Chmykhov MO (ed) Kurganní pam’yatki, yak yavishche davn'ö́ kul'turi. Kiev, pp 3-12

Chibilyov A (1990) Lik stepi (Ekologo-geograficheskiye ocherki o stepnoy zone SSSR). Gidrometeoizdat, Leningrad

Chibilyov A (2002) Steppe and forest-steppe. In: Shahgedanova M (ed) The physical geography of Northern Eurasia. Oxford University Press, Oxford, pp 248-266

Cousins SAO (2009) Extinction debt in fragmented grasslands: paid or not? J Veg Sci 20:3-7. doi:10.1111/j. 1654-1103.2009.05647.x

Cousins SAO, Ohlson H, Eriksson O (2007) Effects of historical and present fragmentation on plant species diversity in semi-natural grasslands in Swedish rural landscapes. Landsc Ecol 22:723-730. doi:10. 1007/s10980-006-9067-1

Deák B, Tóthmérész B, Valkó O, Sudnik-Wójcikowska B, Moysiyenko II, Bragina TM, Apostolova I, Dembicz I, Bykov NI, Török P (2016) Cultural monuments and nature conservation: review on the role of kurgans in the conservation and restoration of steppe vegetation. Biodivers Conserv. doi:10.1007/ s10531-016-1081-2

Debinski DM, Holt RD (2000) A survey and overview of habitat fragmentation experiments. Conserv Biol 14:342-355. doi:10.1046/j.1523-1739.2000.98081.x

Dengler J, Janišová M, Török P, Wellstein C (2014) Biodiversity of Palaearctic grasslands: a synthesis. Agr Ecosyst Environ 182:1-14. doi:10.1016/j.agee.2013.12.015

Didukh YP (ed) (2009) Chervona knyga Ukrainy. Globalkonsalting, Kiev

Dormann CF, Elith J, Bacher S et al (2013) Collinearity: a review of methods to deal with it and a simulation study evaluating their performance. Ecography 36:27-46. doi:10.1111/j.1600-0587.2012.07348.x

Evju M, Blumentrath S, Skarpaas O et al (2015) Plant species occurrence in a fragmented grassland landscape: the importance of species traits. Biodivers Conserv 24:547-561. doi:10.1007/s10531-0140835-y

Fahrig L (2003) Effects of habitat fragmentation on biodiversity. Annu Rev Ecol Evol Syst 34:487-515. doi:10.1146/annurev.ecolsys.34.011802.132419

Fahrig L (2013) Rethinking patch size and isolation effects: the habitat amount hypothesis. J Biogeogr 40:1649-1663. doi:10.1111/jbi.12130

Helm A, Hanski I, Partel M (2006) Slow response of plant species richness to habitat loss and fragmentation. Ecol Lett 9:72-77. doi:10.1111/j.1461-0248.2005.00841.x

Henle K, Davies K, Kleyer M et al (2004) Predictors of species sensitivity to fragmentation. Biodivers Conserv 13:207-251. doi:10.1023/B:BIOC.0000004319.91643.9e

Henwood WD (1998) Editorial: the world's temperate grasslands: a beleaguered biome. Parks 8:1-2

Horsák M, Hájek M, Spitale D et al (2012) The age of island-like habitats impacts habitat specialist species richness. Ecology 93:1106-1114. doi:10.1890/0012-9658-93.5.1106

Ibáñez I, Katz DSW, Peltier D et al (2014) Assessing the integrated effects of landscape fragmentation on plants and plant communities: the challenge of multiprocess-multiresponse dynamics. J Ecol 102:882895. doi:10.1111/1365-2745.12223

Krauss J, Klein A-M, Steffan-Dewenter I, Tscharntke T (2004) Effects of habitat area, isolation, and landscape diversity on plant species richness of calcareous grasslands. Biodivers Conserv 13:14271439. doi:10.1023/B:BIOC.0000021323.18165.58

Kuussaari M, Bommarco R, Heikkinen RK et al (2009) Extinction debt: a challenge for biodiversity conservation. Trends Ecol Evol 24:564-571. doi:10.1016/j.tree.2009.04.011

Laurance W (2008) Theory meets reality: how habitat fragmentation research has transcended island biogeographic theory. Biol Conserv 141:1731-1744. doi:10.1016/j.biocon.2008.05.011

Lavrenko EM, Karamysheva ZV, Nikulina RI (1991) Stepi Evrazii. Scientific Publications, Leningrad

Lienert J (2004) Habitat fragmentation effects on fitness of plant populations: a review. J Nat Conserv 12:53-72. doi:10.1016/j.jnc.2003.07.002

Liira J, Jürjendal I, Paal J (2014) Do forest plants conform to the theory of island biogeography: the case study of bog islands. Biodivers Conserv 23:1019-1039. doi:10.1007/s10531-014-0650-5

Lindborg R, Eriksson O (2004) Historical landscape connectivity affects present plant species diversity. Ecology 85:1840-1845. doi:10.1890/04-0367

Lisetskii F (1992) Periodizatsiya antropogenno obuslovlennoy evolyutsii stepnykh ekosistem. Sov J Ecol 5:17-25

MacArthur RH, Wilson EO (1967) The theory of island biogeography. Princeton University Press, Princeton Magurran AE (1988) Ecological diversity and its measurement. Princeton University Press, Princeton Marynych OM, Shyshchenko PG (2005) Physichna geographya Ukrainy. Znanna, Kiev

Moilanen A, Nieminen M (2002) Simple connectivity measures in spatial ecology. Ecology 83:1131-1145 
Mosyakin SL, Fedoronchuk MM (1999) Vascular plants of Ukraine. A nomenclatural checklist. M. G. Kholodny Institute of Botany, National Academy of Sciences of Ukraine, Kiev

Moysiyenko II (2008) Oglyad rodini Limoniaceae Lincz. flori Ukraïni. Chornomorskyi Bot Zhurnal 4:161174

Moysiyenko II, Sudnik-Wójcikowska B (2006) The flora of kurgans in the steppe zone of southern Ukraine: phytogeographical and ecological aspects. Pol Bot Stud 22:387-398

Moysiyenko II, Sudnik-Wójcikowska B (2010) Kurgans in Ukraine as a refuge of steppe flora. Bull Eur Dry Grassl Group IAVS 6:6-10

Mozolevskiy BM, Polin SV (2005) Kurganÿ skifskogo Gerrosa IV v. do n.é. (Babina, Vodyana i Soboleva mogilÿ), Kiev

Munguía-Rosas MA, Montiel S (2014) Patch size and isolation predict plant species density in a naturally fragmented forest. PLoS One 9:e111742. doi:10.1371/journal.pone.0111742

Niebuhr BBS, Wosniack ME, Santos MC et al (2015) Survival in patchy landscapes: the interplay between dispersal, habitat loss and fragmentation. Sci Rep 5:11898. doi:10.1038/srep11898

Olsson PA, Martensson L-M, Bruun HH (2009) Acidification of sandy grasslands-consequences for plant diversity. Appl Veg Sci 12:350-361. doi:10.1111/j.1654-109x.2009.01029.x

On Protection of Cultural Heritage Act (2000) The law of Ukraine "On protection of cultural heritage" №1805-III of 08.06.2000

Öster M, Cousins SA, Eriksson O (2007) Size and heterogeneity rather than landscape context determine plant species richness in semi-natural grasslands. J Veg Sci 18:859-868. doi:10.1111/j.1654-1103. 2007.tb02602.x

Parker KC (1988) Environmental relationships and vegetation associates of columnar cacti in the northern Sonoran Desert. Vegetatio 78:125-140. doi:10.1007/BF00033422

Pärtel M, Bruun HH, Sammul M (2005) Biodiversity in temperate European grasslands: origin and conservation. In: Integrating efficient grassland farming and biodiversity proceedings of the 13th International Occasional Symposium of the European Grassland Federation, Tartu, pp 1-14

Pausas JG, Austin MP (2001) Patterns of plant species richness in relation to different environments: an appraisal. J Veg Sci 12:153-166. doi:10.2307/3236601

Perehrym MM, Moysiyenko II, Perehrym YS, Mel'nyk VO (2009) Tulipa gesneriana L. (Liliaceae) V Ukraïní. VPC "Kyyivs'kyy universytet", Kiev

Petô Á, Barczi A (eds) (2011) Kurgan studies. An environmental and archaeological multiproxy study of burial mounds in the Eurasian steppe zone. Archaeopress, Oxford

QGIS Development Team (2014) QGIS Geographic Information System. Open Source Geospatial Foundation Project. http://qgis.org/downloads/QGIS-OSGeo4W-1.8.0-1-Setup.exe

R Core Team (2014) R: A language and environment for statistical computing. R Foundation for Statistical Computing, Vienna. https://cran.r-project.org/bin/windows/base/old/3.1.1/

Red List of Kherson Region (2013) Decision of Kherson Regional Council "Chervonyi spysok Khersonskoi oblasti” № 893 of 13.11 .2013

Reitalu T, Sykes MT, Johansson LJ et al (2009) Small-scale plant species richness and evenness in seminatural grasslands respond differently to habitat fragmentation. Biol Conserv 142:899-908. doi:10. 1016/j.biocon.2008.12.020

Rejmánek M, Rejmánková E (2002) Biogeography of artificial islands: effects of age, area, elevation, and isolation on plant species richness. Preslia 74:307-314

Rodríguez-Loinaz G, Amezaga I, Onaindia M (2012) Does forest fragmentation affect the same way all growth-forms? J Environ Manag 94:125-131. doi:10.1016/j.jenvman.2011.06.024

Rosenzweig ML (2004) Applying species-area relationships to the conservation of species diversity. In: Lomolino MV, Heaney LR (eds) Frontiers of biogeography. Sinauer Associates, Sunderland, pp 325343

Rudenko LG (ed) (2007) Natsional'nyy atlas Ukrainy. DNVP Kartografiya, Kyiv

Sih A, Jonsson BG, Luikart G (2000) Habitat loss: ecological, evolutionary and genetic consequences. Trends Ecol Evol 15:132-134. doi:10.1016/S0169-5347(99)01799-1

Solomakha VA (2008) Syntaxonomia roslynnosti Ukrainy. Tretie nablyzhennia. Fitosociocentr, Kiev

Sudnik-Wójcikowska B, Moysiyenko II (2008) The floristic differentiation of microhabitats within kurgans in the desert steppe zone of southern Ukraine. Acta Soc Bot Pol 77:139-147. doi:10.2478/v10119-0100002-6

Sudnik-Wójcikowska B, Moysiyenko II (2010) Zonal character of the flora of kurgans in central and southern Ukraine. Biodivers Res Conserv 17:47-52. doi:10.2478/v10119-010-0002-6

Sudnik-Wójcikowska B, Moysiyenko II (2011) Anthropogenic elements of the Ukrainian landscape and the problem of local steppe restoration. Annales UMCS, Sectio C 66:85-103. doi:10.2478/v10067-0110021-5 
Tscharntke T, Steffan-Dewenter I, Kruess A, Thies C (2002) Contribution of small habitat fragments to conservation of insect communities of grassland-cropland landscapes. Ecol Appl 12:354-363. doi:10. 2307/3060947

Turtureanu PD, Palpurina S, Becker T et al (2014) Scale- and taxon-dependent biodiversity patterns of dry grassland vegetation in Transylvania. Agr Ecosyst Environ 182:15-24. doi:10.1016/j.agee.2013.10.028

Vynokurov DS (2014) Syntaxonomy of xerothermic vegetation of the Ingul River valley (class FestucoBrometea). Part 2. Meadow, shrub and true steppe vegetation. Ukr Bot J 71:537-548

Wilcox BA, Murphy DD (1985) Conservation strategy: the effects of fragmentation on extinction. Am Nat 125:879-887. doi:10.1086/284386

Valdés A, Lenoir J, Gallet-Moron E et al (2015) The contribution of patch-scale conditions is greater than that of macroclimate in explaining local plant diversity in fragmented forests across Europe: drivers of herbaceous species diversity in fragmented forests. Global Ecol Biogeogr 24:1094-1105. doi:10.1111/ geb. 12345 